\title{
PROXIMAL AND DISTAL ESOPHAGEAL CONTRACTIONS IN PATIENTS WITH VIGOROUS OR CLASSIC ESOPHAGEAL CHAGAS' DISEASE
}

\author{
Roberto Oliveira DANTAS and Lilian Rose Otoboni APRILE
}

ABSTRACT - Background - Some patients with achalasia have distal esophageal contraction amplitude in the normal range, a condition called vigorous achalasia, and others have low contraction amplitude, a condition named classic achalasia. The difference in distal contraction amplitude may also be associated with a difference in proximal contraction amplitude. Aim - To study the proximal and distal esophageal contractions in patients with Chagas' disease. Material and Methods - We studied 28 patients with Chagas' disease, all with dysphagia and an esophageal radiologic examination with retention without dilation, and 18 controls. The patients with Chagas' disease had vigorous achalasia (distal amplitude over $34 \mathrm{~mm} \mathrm{Hg}, \mathrm{n}=13$ ) or classic achalasia (distal amplitude below $34 \mathrm{~mm} \mathrm{Hg}, \mathrm{n}=15$ ). We measured the contractions by the manometric method with continuous perfusion at 2, 7,12 and $17 \mathrm{~cm}$ below the upper esophageal sphincter after five swallows of a $5 \mathrm{~mL}$ bolus of water. Results - There was no difference in proximal amplitude of contractions between classic or vigorous achalasia, and controls. In the proximal esophagus there was also no difference in duration or area under curve of contractions. In the distal esophagus, duration and area under curve were lower in classic than vigorous disease. Failed and simultaneous contractions were more frequent in patients than controls. Simultaneous contractions were seen more frequently in classic disease, and peristaltic contractions were seen more frequently in vigorous disease. Conclusion - We did not find differences in proximal esophageal contractions of patients with classical or vigorous esophageal Chagas' disease, except for the higher number of simultaneous contractions seen in classic disease.

HEADINGS - Chagas disease. Esophagus, physiology. Esophageal achalasia.

\section{INTRODUCTION}

There is variation in the esophageal manometric examinations of patients with idiopathic achalasia ${ }^{(15)}$ and patients with Chagas' disease $^{(19)}$. The most frequent alterations, absent or partial lower esophageal sphincter (LES) relaxation and simultaneous low contraction amplitude in the esophageal body, are not of the same grade in all patients in the two diseases.

Some patients have distal amplitude of contraction in the normal range, a condition called vigorous achalasia, and others have low contraction amplitude, a condition named classic achalasia. Patients with vigorous achalasia have a smaller extent of neuronal loss in the myenteric plexus of the esophagus than patients with classic achalasia ${ }^{(13)}$.

The classification of esophageal disease as classical or vigorous does not seem to be of clinical importance ${ }^{(1,3,14)}$. However, the difference in distal esophageal body contraction amplitude may be part of the motility alterations seen also in the proximal esophagus.
The objective of the present investigation was to study the proximal esophageal contractions of patients with Chagas' disease with classic or vigorous achalasia.

\section{MATERIAL AND METHODS}

We studied 28 patients with Chagas' disease and 18 control subjects. The patients with Chagas' disease had dysphagia, a positive serological test for Trypanosoma cruzi infection, radiologic esophageal examination with retention without dilation (distal esophageal diameter $4 \mathrm{~cm}$ or less), and partial or absent LES relaxation in manometric examination. They were 12 men and 16 women aged 37 to 77 years, mean $59.4 \pm 10$ years. After the manometric examination they were classified as having vigorous achalasia (distal amplitude of esophageal contraction over $34 \mathrm{~mm} \mathrm{Hg}, \mathrm{n}=13$ ) or classic achalasia (distal amplitude of esophageal contraction less than $34 \mathrm{~mm} \mathrm{Hg}, \mathrm{n}=15$ ).

The subjects of the control group were submitted to esophageal manometric examination as part of the evaluation of the possibility

Departamento de Clínica Médica da Faculdade de Medicina de Ribeirão Preto - USP, Ribeirão Preto, SP, Brazil

Address for correspondence: Dr. Roberto Oliveira Dantas - Departamento de Clínica Médica - Faculdade de Medicina de Ribeirão Preto - USP - 14049-900 - Ribeirão Preto, SP, Brazil. e-mail: rodantas@fmrp.usp.br 
of gastroesophageal reflux disease. They had heartburn but normal endoscopic and radiological esophageal examination. They were 6 men and 12 women aged 17 to 68 years, mean 42.8 years. The protocol of manometric examination was approved by the Human Research Committee of the "Hospital das Clínicas" of Ribeirão Preto, SP, Brazil.

The manometric examination was performed with a round eightlumen polyvinyl catheter with an outer diameter of $4.5 \mathrm{~mm}$ and an internal diameter of $0.8 \mathrm{~mm}$ (Arndorfer Specialities, Inc, Greendale, Wisconsin, USA). The four proximal lateral openings of the catheter were spaced $5 \mathrm{~cm}$ apart at $90^{\circ}$ angles. They were connected to external pressure transducers ( $p v b$ Medizintechnik Gmb H, Kirchseeon, Germany), which in turn were connected to a PC Polygraph HR (Synectics Medical, Stockholm, Sweden). The manometric signals were stored in a computer. During the manometric recordings, a minimally compliant pneumohydraulic pump (JS Biomedicals, Ventura, CA, USA) perfused distilled water at $0.5 \mathrm{~mL} / \mathrm{min}$ through each lumen.

All individuals were studied in the supine position after $12 \mathrm{hr}$ of fasting. The catheter was introduced through the nose and positioned with the proximal opening situated $2 \mathrm{~cm}$ below the upper esophageal sphincter (UES) and the other openings located 7, 12 and $17 \mathrm{~cm}$ from the UES. Five swallows of a $5-\mathrm{mL}$ bolus of water were performed, with an interval between successive swallows of at least 20 seconds. We studied the contractions at $2 \mathrm{~cm}$ (proximal) and $17 \mathrm{~cm}$ (distal) from the UES. Velocity, percentage of failed, simultaneous or peristaltic contractions were measured from 2 to $7 \mathrm{~cm}$ (proximal) and from 12 to $17 \mathrm{~cm}$ (distal) from the UES.

Using the computer Polygram Upper GI software version 6.4 (Gastrosoft, Stockholm, Sweden) we measured the amplitude, duration and area under the curve (AUC) of contractions, and the velocity of peristaltic contractions measured $5 \mathrm{~cm}$ apart. The complete absence of motor activity after a swallow was considered to be a failure of contraction. Contractions with less than 1 second between onset at recording sites $5 \mathrm{~cm}$ apart were considered simultaneous.

For statistical analysis we used the unpaired $t$ test and the Fisher exact test. Differences were considered significant when $P<0.05$. The results are reported as mean $\pm \mathrm{SD}$ and percentage.

\section{RESULTS}

The mean (SD) age of patients with vigorous disease $(56.1 \pm 9.0$ years) was not different $(P=0.116)$ from the mean age of patients with classic disease $(62.2 \pm 10.2)$.
The amplitude of proximal contractions was the same $(P=0.598)$ in patients with classical or vigorous disease (Table 1), and in controls (Figure 1). In the distal esophagus the amplitude was lower in patients with vigorous disease than in controls $(P<0.01)$. We separated patients with distal amplitude below $34 \mathrm{~mm} \mathrm{Hg}$ (classic disease), in consequence their amplitude was lower than that observed in the control and vigorous groups.

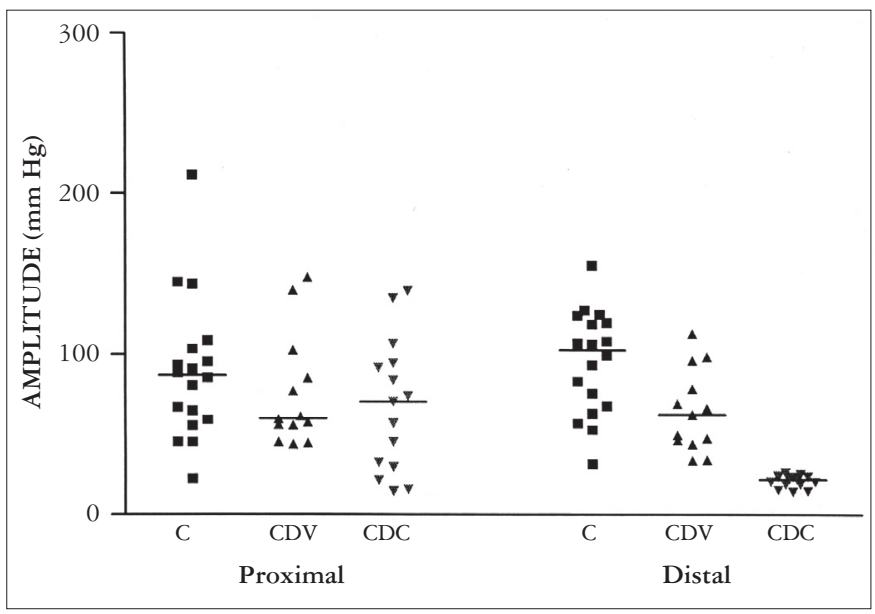

FIGURE 1 - Amplitude of esophageal contractions in the control subjects (C) and patients with Chagas' disease with vigorous (CDV) or classic (CDC) achalasia, measured at $2 \mathrm{~cm}$ (proximal) and $17 \mathrm{~cm}$ (distal) from the upper esophageal sphincter. The horizontal bars represent the medians

The duration of contractions in the proximal esophagus $(P=$ 0.146 ) was the same in vigorous and classic disease (Table 1). In the distal esophagus the duration was shorter in classic than in vigorous disease $(P<0.01$, Figure 2$)$. Similar results were observed for the AUC. There was no difference in proximal esophagus between classic and vigorous disease $(P=0.168$, Table 1$)$, but there was a difference in distal esophagus $(P<0.001$, Figure 3$)$, and difference between controls and Chagas' disease patients $(P$ $<0.05)$. There was no differences in the velocity of peristaltic contractions $(P>0.05$, Table 1$)$.

Failed and simultaneous contractions were more frequent in patients than in controls, and peristaltic contractions more frequent in controls than in patients (Table 1). There was no difference in the frequency of failed contractions between classic and vigorous disease

TABLE 1 - Results of esophageal motility evaluation in patients with classic or vigorous achalasia caused by Chagas' disease and control subjects, measured at $2 \mathrm{~cm}$ (proximal) and $17 \mathrm{~cm}$ (distal) below the upper esophageal sphincter (mean \pm SD and percentage)

\begin{tabular}{|c|c|c|c|c|c|c|}
\hline & & & \multicolumn{4}{|c|}{ Chagas' disease } \\
\hline & \multicolumn{2}{|c|}{ Controls $(\mathrm{n}=18)$} & \multicolumn{2}{|c|}{ Classic $(n=15)$} & \multicolumn{2}{|c|}{ Vigorous $(n=13)$} \\
\hline & Proximal & Distal & Proximal & Distal & Proximal & Distal \\
\hline Amplitude (mm Hg) & $89.3 \pm 44.1$ & $95.5 \pm 32.2^{\mathrm{a}}$ & $67.5 \pm 41.3$ & $21.3 \pm 4.0$ & $75.2 \pm 35.0$ & $65.0 \pm 25.5$ \\
\hline Duration (seconds) & $2.5 \pm 0.8$ & $4.2 \pm 1.3$ & $2.4 \pm 0.8$ & $3.4 \pm 0.9^{\mathrm{a}}$ & $2.9 \pm 1.0$ & $4.5 \pm 1.3$ \\
\hline $\operatorname{AUC}(\mathrm{mm} \mathrm{Hg} \times \mathrm{s})$ & $105.5 \pm 53.4$ & $222.5 \pm 116.7^{b}$ & $74.2 \pm 50.0$ & $46.3 \pm 16.3^{\mathrm{a}}$ & $106.3 \pm 69.5$ & $148.0 \pm 56.9$ \\
\hline Velocity $(\mathrm{cm} / \mathrm{s})$ & $1.8 \pm 0.6$ & $3.3 \pm 0.7$ & $1.7 \pm 0.8$ & $3.5 \pm 0.5$ & $1.9 \pm 1.1$ & $2.8 \pm 1.1$ \\
\hline Failed (\%) & $20.0^{c}$ & $8.9^{c}$ & 36.0 & 25.3 & 32.3 & 21.5 \\
\hline Simultaneous (\%) & $4.4^{\mathrm{c}}$ & $23.3^{c}$ & $34.7^{\mathrm{a}}$ & $72.0^{\mathrm{a}}$ & 9.2 & 47.7 \\
\hline Peristaltic (\%) & $75.6^{\mathrm{c}}$ & $67.8^{c}$ & $29.3^{\mathrm{a}}$ & $2.7^{\mathrm{a}}$ & 58.5 & 30.8 \\
\hline
\end{tabular}

AUC - Area under curve $\quad a p<0.01$ vs vigorous $\quad{ }^{b} P<0.05$ vs vigorous $\quad{ }^{c} P<0.05$ vs Chagas' disease 


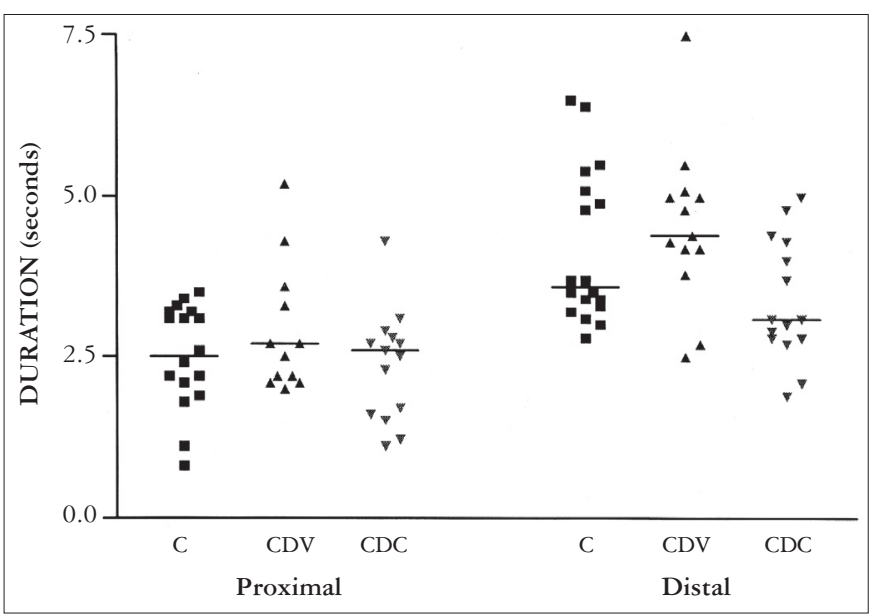

FIGURE 2 - Duration of esophageal contractions in the control subjects (C) and patients with Chagas' disease with vigorous (CDV) or classic (CDC) achalasia, measured at $2 \mathrm{~cm}$ (proximal) and $17 \mathrm{~cm}$ (distal) from the upper esophageal sphincter. The horizontal bars represent the medians

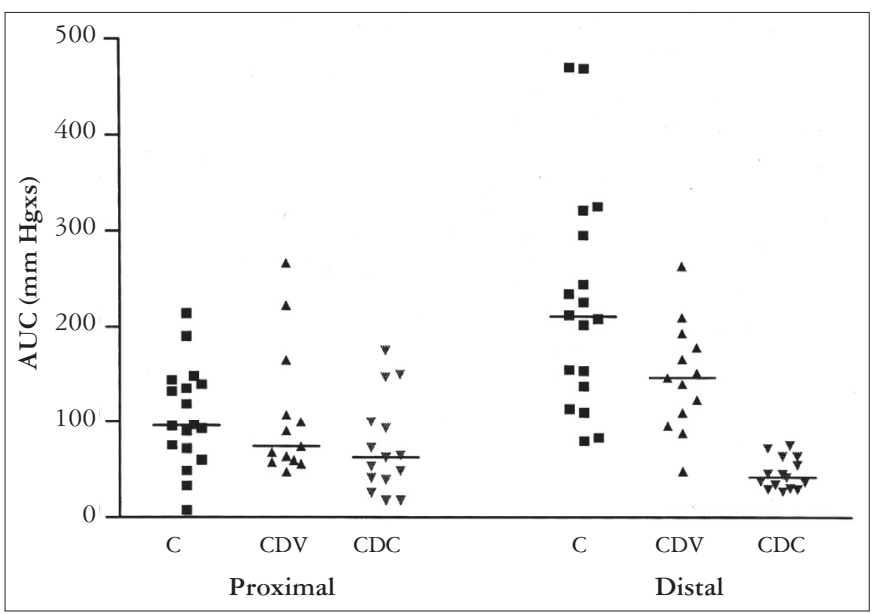

FIGURE 3 - Area under curve (AUC) of esophageal contractions in the control subjects $(\mathrm{C})$ and patients with Chagas' disease with vigorous (CDV) or classic (CDC) achalasia, measured at 2 $\mathrm{cm}$ (proximal) and $17 \mathrm{~cm}$ (distal) from the upper esophageal sphincter. The horizontal bars represent the medians

$(P>0.05)$. Patients with classic disease had more simultaneous and fewer peristaltic contractions than patients with vigorous disease $(P<0.01$, Table 1$)$.

In the proximal esophagus a difference was observed between classic and vigorous disease in the proportion of simultaneous contractions, which was higher in the classic disease, and in the proportion of peristaltic disease, which was higher in vigorous disease.

\section{DISCUSSION}

Our results showed that there is no difference in proximal esophageal contractions of chagasic patients with classical or vigorous achalasia.

The difference between the two presentations of the disease is the amplitude of distal esophageal contractions, which is in the normal range in the vigorous presentation and low in the classic presentation. Low amplitude is most frequently seen in the disease ${ }^{(2,9)}$. There is no difference in the UES and LES pressures or in the proportion of patients with dysphagia ${ }^{(3)}$. The classic presentation shows more failed contractions than the vigorous one ${ }^{(3)}$, a fact that we did not observe in the present study. We found more simultaneous contractions in classic than in vigorous disease.

A pathologic study of idiopathic achalasia suggested that the myenteric neuron impairment in vigorous disease is much less important than in classic disease ${ }^{(13)}$. Patients with Chagas' disease may have also different grades of esophageal myenteric plexus $\operatorname{los} s^{(11)}$, although no functional studies have been performed in correlation with myenteric plexus studies. Even patients without dysphagia and normal esophageal radiologic examination have a decrease in esophageal contraction amplitude, but not so important as in patients with dysphagia ${ }^{(9)}$.

Except for the proportion of simultaneous and peristaltic contractions, there is no difference between the proximal esophageal response to swallow between classic and vigorous disease. Chagas' disease involves more the distal ${ }^{(19)}$ than the proximal esophagus ${ }^{(6)}$. The different types of muscle, striated in the proximal esophagus and smooth in the distal esophagus ${ }^{(17)}$, and in the innervation control ${ }^{(18)}$ may explain the more important impairment of distal esophageal motility in one group of patients than in another without causing the same differences in proximal motility.

Similar to what we found in Chagas' disease, in other diseases that involve distal esophageal contractions we did not see a change in the proximal contractions ${ }^{(4,5)}$, except in idiopathic achalasia which shows a decrease in esophageal contraction amplitude ${ }^{(6,10)}$. There is some difference in esophageal involvement between Chagas' disease and idiopathic achalasia ${ }^{(7)}$ but there are no studies comparing proximal esophageal contraction in patients with vigorous or classic idiopathic achalasia. It is possible that patients with the classic disease have low contraction amplitude in the proximal esophagus.

In this group of patients with similar clinical and radiologic evaluations the age of patients with the more advanced presentation of the disease (classic) tended to be older than that of patients with the less advanced presentation of the disease (vigorous). This is the same trend we found in our previous work ${ }^{(3)}$, suggesting the possibility that the disease progresses to a more important impairment of esophageal in older patient. The loss of neurons is seen at a more advanced age ${ }^{(16)}$, with consequences on esophageal motility ${ }^{(12)}$.

Each subject was asked to perform five wet swallows because in a previous study we found that five swallows provide the same manometric quantitative evaluation as an additional five swallows in normal subjects, patients with Chagas' disease and patients with idiopathic achalasia ${ }^{(8)}$. We used patients with heartburn as controls because these patients do not have alterations in proximal esophageal contractions ${ }^{(5)}$.

In conclusion, we did not find differences in proximal esophageal contraction amplitude, duration or velocity of peristalsis between chagasic patients with classic or vigorous esophageal disease. The classic form of the disease produces more simultaneous contractions than the vigorous form. The results suggest that the vigorous disease represents a less intense form of chagasic esophagopathy, a fact that may be associated with a less important destruction of the myenteric plexus. 
Dantas RO, Aprile LRO. Contrações esofágicas proximais e distais em pacientes com doença de Chagas vigorosa ou clássica. Arq Gastroenterol 42(1):9-12.

RESUMO - Racional - Alguns pacientes com acalásia têm contrações com amplitudes compatíveis com a normalidade, o que recebe o nome de acalásia vigorosa, e outros têm amplitude diminuída, chamada de acalásia clássica. A hipótese deste estudo é de que esta diferença na parte distal do esôfago pode acontecer também na parte proximal. Objetivo - Avaliar as contrações proximais e distais de pacientes com doença de Chagas. Material e Método - Foram estudados 28 pacientes com doença de Chagas todos com disfagia e exame radiológico do esôfago com retenção do meio de contraste, sem dilatação, e 18 controles. Treze pacientes com doença de Chagas tinham a forma vigorosa (amplitude distal acima de $34 \mathrm{~mm} \mathrm{Hg}$ ), e 15 tinham a forma clássica (amplitude distal abaixo de $34 \mathrm{~mm} \mathrm{Hg}$ ). As contrações foram medidas pelo método manométrico com perfusão contínua a 2, 7, 12 e $17 \mathrm{~cm}$ abaixo do esfíncter superior do esôfago, após cinco deglutições de $5 \mathrm{~mL}$ de água. Resultados - Não houve diferenças na amplitude em parte proximal do esôfago entre acalásia clássica ou vigorosa, e com os controles. Também não houve diferença na parte proximal na duração e área sob a curva entre acalásia vigorosa e clássica. Na parte distal a duração e área sob a curva foram menores na doença clássica do que na vigorosa. Contrações falhas e simultâneas foram mais freqüentes em pacientes do que em controles. Contrações simultâneas foram mais freqüentes na doença clássica, e contrações peristálticas foram mais freqüentes na doença vigorosa. Conclusão - Não foram observadas diferenças nas contrações proximais do esôfago de pacientes com doença de Chagas na forma clássica ou vigorosa, com exceção do maior número de contrações simultâneas nos pacientes com a doença clássica.

DESCRITORES - Doença de Chagas. Esôfago, fisiologia. Acalásia esofágica.

\section{REFERENCES}

1. Camacho-Lobato L, Katz PO, Eveland J, Vela M, Castell DO. Vigorous achalasia. Original description requires minor change. J Clin Gastroenterol 2001;33:375-7.

2. Dantas RO, Deghaide NHS, Donadi EA. Esophageal motility of patients with Chagas' disease and idiopathic achalasia. Dig Dis Sci 2001;46:1200-6.

3. Dantas RO. Vigorous achalasia in Chagas' disease. Dis Esophagus 2002;15:305-8

4. Dantas RO, Aprile LRO. Contrações da musculatura proximal do esôfago no esôfago em quebra-nozes e na esclerose sistêmica. J Bras Gastroenterol 2002;2:110-4.

5. Dantas RO, Aprile LRO. Esophageal striated muscle contractions in patients with gastroesophageal reflux symptoms. Dig Dis Sci 2002;47:2586-90.

6. Dantas RO, Aprile LRO, Aben-Athar CG, Miranda ALM. Esophageal striated muscle contractions in patients with Chagas' disease and idiopathic achalasia. Braz J Med Biol Res 2002;35:677-83.

7. Dantas RO. Comparação entre acalásia idiopática e acalásia consequente à doença de Chagas. Arq Gastroenterol 2003;40:126-30.

8. Dantas RO. Effect of successive swallows on oesophageal motility of normal volunteers, patients with Chagas' disease and patients with idiopathic achalasia. Neurogastroenterol Motil 2003;15:57-62.

9. Dantas RO. Motilidade do esôfago no paciente com doença de Chagas sem megaesôfago. GED Gastroenterol Endosc Dig 2003;22:79-84

10. Dunaway PM, Maydonovitch CL, Wong RKH. Characterization of esophageal striated muscle in patients with achalasia. Dig Dis Sci 2000;45:285-8.

11. Ferreira-Santos R. Aperistalsis of the esophagus and colon (megaesophagus and megacolon) etiologically related to Chagas' disease. Am J Dig Dis 1961;6:700-26.
12. Ferriolli E, Dantas RO, Oliveira RB, Braga FJHN. The influence of ageing on oesophageal motility after ingestion of liquids with different viscosities. Eur $J$ Gastroenterol Hepatol 1996;8:793-8.

13. Goldblum JR, Rice TW, Richter JE. Histopathologic features in esophagomyotomy specimens from patients with achalasia. Gastroenterology 1996;111:648-54.

14. Goldenberg SP, Burrell M, Fette GG, Vos C, Traube M. Classic and vigorous achalasia: a comparison of manometric, radiographic and clinical findings. Gastroenterology 1991;101:743-8.

15. Hirano I, Tatum RP, Shi G, Sang Q, Joehl RJ, Kahrilas PJ. Manometric heterogeneity in patients with idiopathic achalasia. Gastroenterology 2001;120:789-98.

16. Köberle F. Chagas' disease and Chagas' syndrome: the pathology of American Trypanosomiasis. Adv Parasitol 1968,6:63-73.

17. Meyer GW, Austin RM, Brady CE III, Castell DO. Muscle anatomy of the human esophagus. J Clin Gastroenterol 1986;8:131-4.

18. Murray JA, Clouse RE, Conklin JL. Components of the standard oesophageal manometry. Neurogastroenterol Motil 2003;15:591-606.

19. Oliveira RB, Rezende-Filho J, Dantas RO, Iazigi N. The spectrum of esophagea motor disorders in Chagas' disease. Am J Gastroenterol 1995;90:1119-24. 